7RU, England, UK, to whom all future submissions should be sent and editorial questions addressed. Also happily chosen as the global publisher, is the Journals Department, Cambridge University Press, The Edinburgh Building, Shaftesbury Road, Cambridge CB2 2RU, England, UK (see Announcement below). Viability being of anxious concern in the present, uncertain times, it is interesting to note that Cambridge University Press is the oldest surviving press in the world.

Yes of course it will be a wrench after more than a quarter of a century to be no longer the Editor of a leading journal of world-wide circulation and evident influence on a vital topic or, for the last 22 years, duality of topics. But although passing on primary responsibility to a well-qualified and keen family member, we'll henceforth, as latterly, be looking after the section of Book Reviews, receiving review copies of books and passing on the residue each year to IUCN and/or the International Academy of the Environment (based, respectively, near to and in Geneva), serving on the Board of Advisory Editors with special responsibility for matters pertaining to The Biosphere, and in those and some other ways - such as administering the owning Foundation for Environmental Conservation - serving the cause of what we confidently expect to be an everstronger and more influential journal. ${ }^{\dagger}$

NiCHOLAS POLUNIN

16 November 1995

\footnotetext{
tWe also aspire to foster the long-dreamed-of global network of Biosphere Clubs so that they become recognized and treated as effective environmental/conservational watch-dogs - duly guided in policy matters by a revived World Council For The Biosphere - while seeking a Biosphere Fund sufficient to award a major Biosphere Prize and 5 or 6 satellite prizes each year to be announced on Biosphere Day.
}

\title{
ANNOUNCEMENT
}

\section{Change in Publisher of Environmental Conservation to Cambridge University Press*}

A S of 1 January 1996, the Journal Environmental Conservation will be published by Cambridge University Press. Correspondence concerning subscriptions, permissions, and other matters related to the publication and distribution of the Journal, should henceforth be directed to:

\section{In the UK and rest of the world:}

\author{
Journals Department \\ Cambridge University Press \\ The Edinburgh Building \\ Shaftesbury Road \\ Cambridge CB2 2RU \\ England, UK
}

Tel. (+44) 1223312393
Fax: (+44) 1223315052

\section{In the USA, Canada, and Mexico:}

Journals Department

Cambridge University Press

40 West 20th Street

New York

NY 10011-4211

USA

$$
\begin{aligned}
& \text { Tel. +1 (212) } 9243900 \\
& \text { Fax: +1 (212) } 6913239
\end{aligned}
$$

\footnotetext{
* This change promises to benefit the owning Foundation for Environmental Conservation and its capabilities of helping the Environmental/Conservational movement as, instead of having to pay most of the overheads of producing each issue of Environmental Conservation, for the substantial benefit of its latterly mere distributor and with the Editor giving his entire services for the good of the cause, the Foundation will receive revenues from the not-for-profit oldest press in the world. Apart from voluntary donations and grants towards reimbursement of the cost of editing and publishing their papers from satisfied Authors or their institutions which it is hoped will continue, the amounts received by the Foundation will depend mainly on subscriptions to its Journal. These are expected to increase greatly in the hands of this distinguished Publisher which is to offer subscriptions to individuals at less than half of the institutional price. Meanwhile the Foundation's headquarters and most overheads are contributed by its President, who plans to continue in that capacity just as long as he is able to and wanted.
} 